\title{
Comparison of Auditory Effects after IMRT with Concurrent Cisplatin for Locally Advanced Head and Neck Cancer
}

\author{
SUSHIL KUMAR AGGARWAL ${ }^{1}$, NILESH KUMAR MANI², SUNIL CHOUDHARY3 ${ }^{3}$, ABHIJIT MANDAL ${ }^{4}$, NEHA GUPTA
}

\section{ABSTRACT}

Introduction: Head and neck cancer is among the most common malignancies in developing countries like India. The treatment modality for head and neck cancers is usually radiotherapy which can be used either after surgery or combined with chemotherapy. However, radiation therapy can damage the ear from pharyngotympanic tube to the auditory pathway upto brain-stem, causing hearing loss due to ultrastructural changes in organ of corti. Long term survivors can experience Sensorineural Hearing Loss (SNHL) due to the combined ototoxic effects of radiotherapy and cisplatin.

Aim: To study the effects of Intensity-Modulated Radiation Therapy (IMRT) along with chemotherapy on hearing, in head and neck cancer patients.
Materials and Methods: Twenty three patients were treated on Linear Accelerator- Varian Unique Performance with $6 \mathrm{MV}$ photon and received dose 70 Gy in 35 fractions over 6.5 weeks; either by sequential IMRT (SEQ) or by Simultaneous Integrated Boost IMRT (SIB). They also received cisplatin $35 \mathrm{mg} / \mathrm{m}^{2}$ once weekly concurrently with radiotherapy for 6-8 weeks. Pre and post-radiotherapy Pure Tone Audiometry (PTA) were done to assess the hearing loss.

Results: Most of our patients developed either conductive hearing loss or mixed hearing loss. Only two patients developed sensorineural hearing loss.

Conclusion: Most of the patients developed mild hearing loss before and after chemoradiotherapy, indicating that both the arms of IMRT (radiotherapy) did not have any major influence on the inner ear.

Keywords: Chemoradiotherapy, Hearing loss, Radiotherapy

\section{INTRODUCTION}

Head and neck cancer is the fifth most common malignancy in the world, though it is the most common malignancy in developing countries like India. Total head and neck cancer cases are over half a million all over the world [1]. About $70 \%$ of the affected patients present with clinically advanced disease, either at the primary site or in the cervical lymph nodes [2]. Locoregional control is critical in management of head and neck cancers as recovery is often difficult. Multimodal approach has been found to reduce the risk of local failure and improves survival. Radiotherapy is a major treatment modality for head and neck cancers and is used either exclusively or combined with surgery or chemotherapy [1]. In cases of oropharynx, larynx and hypopharynx, concurrent chemoradiotherapy has an upper hand in its definitive treatment as monotherapy has been found to be less responsive and it has an advantage over surgery in preservation of organ. Strategies of organ preservation using RT and chemotherapy has been the main stay of treatment [2]. Various strategies have been adopted to protect the sensitive structures like brain stem, spinal cord, optic chiasma, cornea and the pituitary gland, but no strategies have been adopted to protect the inner ear till date [3].

Hearing is an important sense for life because it is through hearing that interactions between the environment and society are established. Although there are different degrees of hearing loss, any impediment in conduction of sounds to the auditory nervous system signifies loss of message content, and this may give rise to emotional and social limitations and/or restrictions [4]. Radiation damage can occur from the pharyngotympanic tube to the brain stem auditory pathway, causing hearing loss due to changes in Organ of Corti caused by damage to hair cells, cochlea, stria vascular and cochlear neurons $[5,6]$. Long term survivors can experience SNHL due to the combined effect of radiotherapy and ototoxicity induced by cisplatin [1]. Higher frequencies are affected first, which may subsequently affect mid and low frequencies [6].
Borsanyi S et al., and Leach W demonstrated that SNHL occurs due to damage to the mitotic cells of sensory epithelium post radiotherapy and also because of changes in vascular structure interfering with supply of oxygen and metabolites to the cochlea $[7,8]$. Conductive hearing loss occurs due to vascular dilatation and oedema of mucosa and eustachian tube leading to middle ear effusion and haemorrhage. Ossicular necrosis also occur postradiotherapy leading to conductive hearing loss [1].

To improve patient's life, it is essential to monitor hearing thresholds during the early diagnosis of cochlea damage $[5,9]$. The radiation dose reaching the structures of the auditory system may be almost $100 \%$, depending on the location and size of the tumour, like in nasopharyngeal carcinoma [10]. But with IMRT, hearing can be protected by administering limited radiation doses to the inner and middle ear [11]. Conventional radiotherapy is associated with good locoregional control at the cost of normal tissue toxicity, but with the development of newer techniques like IMRT, highly conformal treatment can be delivered with sparing of normal tissue.

The purpose of this study was to assess the level of auditory impairment caused due to chemoradiotherapy by administering newer techniques of radiotherapy, like IMRT.

\section{MATERIALS AND METHODS}

In this study, head and neck cancers patient registered in radiotherapy department who were planned to undergo concurrent chemoradiotherapy were included. The specific inclusion criteria were:

- Histopathologically confirmed patients of oropharyngeal, laryngeal and hypopharyngeal cancer

- Squamous cell histology

- $\quad$ TNM stage: III-IVA (AJCC seventh edition staging system)

- No history of any surgery, chemotherapy and radiotherapy for head and neck malignancy 
- Age group- 18- 65 years.

- Karnofsky Performance Scale $\geq 60$

- $\quad H b \geq 10, T L C \geq 4000$, Platelet $\geq 100,000$

- $\quad$ Serum Creatinine $\leq 1.4$; Creatinine clearance $\geq 60$

Patients with history of hearing loss or ear diseases were excluded from the study.

All patients were informed about the study and the purpose of conducting the study was explained. Written consents were taken before taking the ear swab. Ethical clearance was obtained from the ethical committee of the institute dated $31^{\text {st }}$ July, 2017 having registration number ECR/526/Inst/UP/2014 Dt 31.1.14.

Complete otologic examination of all the patients were done prior to treatment in ENT department, BHU. The study consisted of 19 males and 4 females with age ranging from 35 years to 65 years. The site of lesions along with group staging in relation to number of patients studied is shown in [Table/Fig-1].

\begin{tabular}{|c|c|c|}
\hline Characteristics & $\underset{n=11}{S \text { SIB }}$ & $\begin{array}{l}\text { SEQ } \\
\mathrm{n}=12\end{array}$ \\
\hline \multicolumn{3}{|l|}{ Primary site } \\
\hline Oropharynx & 2 & 5 \\
\hline Larynx & 6 & 5 \\
\hline Hypopharynx & 3 & 2 \\
\hline \multicolumn{3}{|l|}{ Group stage } \\
\hline III & 2 & 4 \\
\hline Iva & 9 & 8 \\
\hline \multicolumn{3}{|l|}{ T stage } \\
\hline $\mathrm{T} 1$ & 0 & 1 \\
\hline T2 & 2 & 3 \\
\hline T3 & 3 & 4 \\
\hline $\mathrm{T} 4 \mathrm{a}$ & 6 & 4 \\
\hline \multicolumn{3}{|l|}{$\mathrm{N}$ stage } \\
\hline No & 4 & 5 \\
\hline N1 & 4 & 2 \\
\hline $\mathrm{N} 2 \mathrm{~b}$ & 1 & 3 \\
\hline N2c & 2 & 2 \\
\hline \multicolumn{3}{|c|}{$\begin{array}{l}\text { [Table/Fig-1]: Site of lesion with respect to number of patients in different treatment } \\
\text { groups. } \\
\text { SIB: Simultaneous Integrated Boost IMRT; SEQ: Sequential IMRT }\end{array}$} \\
\hline
\end{tabular}

These patients were treated on Linear Accelerator- Varian Unique Performance with $6 \mathrm{MV}$ photon and received dose 70 Gy in 35 fractions over 6.5 weeks either by sequential IMRT (SEQ) or by IMRT SIB. They also received cisplatin $35 \mathrm{mg} / \mathrm{m}^{2}$ once weekly concurrently with radiotherapy for 6-8 weeks.

PTA were obtained before treatment to assess individual baseline hearing thresholds. The hearing assessment included audiologic history, air and bone conduction thresholds and impedance audiometry. Testing was performed in a sound proof audiometric room. Masking was used, if indicated. Bone and air conduction thresholds (250-4,000 and 250-8,000 Hz respectively) were obtained using a pure tone audiometer. Impedance audiometry was performed in patients showing conductive hearing loss.

Hearing loss was classified according to World Health Organization (WHO) as follows: Normal: $<15 \mathrm{~dB}$, Slight: 16-25 dB, mild: 26$40 \mathrm{~dB}$, Moderate: $41-55 \mathrm{~dB}$, moderately severe: $56-70 \mathrm{~dB}$, severe: 71-90 dB, Profound: $>91 \mathrm{~dB}$. Hearing loss of more than $15 \mathrm{~dB}$ either in the speech frequency, in the high frequency, or in both before and after therapy were considered significant [3-5].

PTA was obtained in all the patients after an interval of 3 months post-chemoradiotherapy. Patients having audiograms less than 3 months post-chemoradiotherapy were not included.
Ototoxicity was measured using pre and post-RT audiograms. Hearing threshold change was determined relative to each patient's baseline.

\section{STATISTICAL ANALYSIS}

Continuous variables were summarized using mean (SD) or median (IQR) based on normal distribution tested using KolmogorovSmirnov test.

\section{RESULTS}

The mean age in the study was 46 years and males (>80\%) were more common than females. The type of hearing loss in different ears, both before treatment and after treatment of 3 months, has been shown in [Table/Fig-2]. The degree of hearing loss in different ears, both before treatment and after treatment of 3 months, is shown in [Table/Fig-3].

\begin{tabular}{|l|c|}
\hline Type of hearing loss & Number of ears \\
\hline Sensorineural hearing loss & 2 \\
\hline Conductive hearing loss & 20 \\
\hline Mixed hearing loss & 3 \\
\hline Normal hearing & 12 \\
\hline Improved hearing & 9 \\
\hline [Table/Fig-2]: Audiometry results after completion of concurrent chemoradiotherapy.
\end{tabular}

\begin{tabular}{|l|c|}
\hline Degree of hearing loss (in dB) & Number of ears \\
\hline $0-25$ & 20 \\
\hline $26-40$ & 24 \\
\hline $41-55$ & 2 \\
\hline More than 55 & 2 \\
\hline [Table/Fig-3]: Degree of hearing loss after concurrent chemoradiotherapy. \\
\hline
\end{tabular}

Impedance audiometry showed normal type A curve in 30 ears whereas type C curve was seen in 12 ears. B-type curve was present in 4 ears. Acoustic reflex was absent in 12 ears.

Hearing assessment was done by PTA before commencement of treatment and three months after completion of chemoradiotherapy but no significant difference was observed in the mean value of pure tone audiometry between the two treatment arms [Table/Fig-4]. A total of 16 ears showed Eustachian tube dysfunction post radiotherapy.

\begin{tabular}{|l|c|c|c|c|c|}
\hline & Mean & SD & Median & Inter quartile range & p-value \\
\hline Rt Ear Pre RT & 27.25 & 7.97 & 24.75 & $21.0-28.75$ & \multirow{2}{*}{0.13} \\
\hline Rt ear post RT & 29.72 & 10.82 & 25.25 & $24.5-29.00$ & \\
\hline Lt ear pre RT & 29.39 & 10.27 & 25.60 & $22.5-33.75$ & \multirow{2}{*}{0.38} \\
\cline { 1 - 4 } Lt ear post RT & 32.00 & 14.42 & 25.00 & $24.5-33.75$ & \\
[Table/Fig-4]: Pre and Post RT PTA values of patients receiving Simultaneous \\
Integrated Boost (SIB) IMRT (11 patients). \\
The pre-RT and post-RT change in decibels of Left ear and right ear were tested using paired \\
t-test and were found to be statistically non- significant $(\mathrm{p}=0.13)$ and $(\mathrm{p}=0.38)$ respectively \\
\hline
\end{tabular}

\section{PTA Analysis}

The data was analyzed using the computer software program, Statistical Package for Social Sciences-version 16.0 (SPSS-16.0) for Windows. Continuous variables were summarized using mean (SD) or median (IQR) based on normal distribution tested using Kolmogorov-Smirnov test.

The pre-RT and post-RT change in decibels of Left ear and right ear were tested using paired t-test and were found to be statistically non- significant [Table/Fig-5,6].

The change in $\mathrm{dB}$ in the right ear and left ear between pre- and post-RT among SIB and SEQ were found to be non- significant ( $p=0.78$ and 0.44 respectively). 


\begin{tabular}{l|c|c|c|c|c|}
\hline & Mean & SD & Median & Inter quartile range & p-value \\
\hline Rt Ear Pre-RT & 25.43 & 4.81 & 24.87 & $21.56-26.68$ & \multirow{2}{*}{0.21} \\
\cline { 1 - 5 } Rt ear Post-RT & 26.70 & 3.41 & 26.10 & $23.93-28.25$ & \\
\hline Lt ear Pre-RT & 27.85 & 7.54 & 25.87 & $22.75-27.68$ & \multirow{2}{*}{0.81} \\
\cline { 1 - 4 } Lt ear Post-RT & 27.54 & 4.50 & 26.75 & $23.93-29.31$ & \\
[Table/Fig-5]: Pre and Post RT PTA values of patients receiving Sequential (SEQ) \\
IMRT (12 patients).
\end{tabular}

\begin{tabular}{|c|c|c|c|}
\hline S. No. & Patient name & Pre-RT PTA & Post-RT PTA \\
\hline 1. & $\begin{array}{l}\text { Right } \\
\text { Left }\end{array}$ & $\begin{array}{l}43+42+45+52 / 4=45.5 \\
52+50+55+65 / 4=55.5\end{array}$ & $\begin{array}{c}45+50++60+80 / 4=58.75 \\
58+62+73+85 / 4=69.5\end{array}$ \\
\hline 2. & $\begin{array}{l}\text { Right } \\
\text { Left }\end{array}$ & $\begin{array}{l}20+22+20+20 / 4=20.5 \\
22+22+20+22 / 4=21.5\end{array}$ & $\begin{array}{l}25+22+26+32 / 4=26.25 \\
20+22+25+32 / 4=24.75\end{array}$ \\
\hline 3. & $\begin{array}{l}\text { Right } \\
\text { Left }\end{array}$ & $\begin{array}{c}25+24+25+25 / 4=24.75 \\
25+25+23+25 / 4=24.5\end{array}$ & $\begin{array}{l}25+24+24+25 / 4=24.5 \\
25+23+25+25 / 4=24.5\end{array}$ \\
\hline 4. & $\begin{array}{l}\text { Right } \\
\text { Left }\end{array}$ & $\begin{array}{c}20+22+20+24 / 4=21.5 \\
22+20+22+25 / 4=22.25\end{array}$ & $\begin{array}{c}25+25+22+32 / 4=26 \\
25+22+20+25 / 4=23.75\end{array}$ \\
\hline 5. & $\begin{array}{l}\text { Right } \\
\text { Left }\end{array}$ & $\begin{array}{c}32+35+37+50 / 4=38.5 \\
35+40+40+62 / 4=44.25\end{array}$ & $\begin{array}{l}30+32+35+40 / 4=34.25 \\
32+35+40+42 / 4=37.25\end{array}$ \\
\hline 6. & $\begin{array}{l}\text { Right } \\
\text { Left }\end{array}$ & $\begin{array}{c}25+25+21+22 / 4=23.25 \\
40+38+40+40 / 4=39.5\end{array}$ & $\begin{array}{c}25+25+25+26 / 4=25.25 \\
25+21+25+25 / 4=24\end{array}$ \\
\hline 7. & $\begin{array}{l}\text { Right } \\
\text { Left }\end{array}$ & $\begin{array}{l}20+22+22+25 / 4=21.75 \\
20+20+22+25 / 4=21.75\end{array}$ & $\begin{aligned} 25+27+30+32 / 4 & =28.5 \\
25+28+31+35 / 4 & =29.75\end{aligned}$ \\
\hline 8. & $\begin{array}{l}\text { Right } \\
\text { Left }\end{array}$ & $\begin{array}{l}26+27+24+30 / 4=26.75 \\
28+25+30+28 / 4=27.75\end{array}$ & $\begin{array}{c}24+20+20+30 / 4=23.5 \\
22+20+20+30 / 4=23\end{array}$ \\
\hline 9. & $\begin{array}{l}\text { Right } \\
\text { Left }\end{array}$ & $\begin{array}{l}25+25+25+24 / 4=24.75 \\
25+22+25+25 / 4=24.25\end{array}$ & $\begin{array}{l}22+22+23+24 / 4=22.75 \\
22+22+23+24 / 4=22.75\end{array}$ \\
\hline 10. & $\begin{array}{l}\text { Right } \\
\text { Left }\end{array}$ & $\begin{array}{c}22+20+20+22 / 4=21 \\
22+21+25+22 / 4=22.5\end{array}$ & $\begin{array}{c}30+28+28+30 / 4=29 \\
28+25=25+27 / 4=26.25\end{array}$ \\
\hline 11. & $\begin{array}{l}\text { Right } \\
\text { Left }\end{array}$ & $\begin{array}{l}26+24+27+26 / 4=25.75 \\
26+28+22+25 / 4=25.25\end{array}$ & $\begin{array}{c}28+26+28+28 / 4=27.5 \\
28+30+26+28 / 4=28\end{array}$ \\
\hline 12. & $\begin{array}{l}\text { Right } \\
\text { Left }\end{array}$ & $\begin{array}{c}36+38+37+50 / 4=39 \\
32+30+30+43 / 4=33.75\end{array}$ & $\begin{array}{l}38+35+36+52 / 4=40.75 \\
32+30+34+42 / 4=35.75\end{array}$ \\
\hline 13. & $\begin{array}{l}\text { Right } \\
\text { Left }\end{array}$ & $\begin{array}{c}22+20+22+22 / 4=21.5 \\
22+20+20+22 / 4=21\end{array}$ & $\begin{array}{c}25+22+26+25 / 4=24.5 \\
26+25+24+26 / 4=25.25\end{array}$ \\
\hline 14. & $\begin{array}{l}\text { Right } \\
\text { Left }\end{array}$ & $\begin{array}{c}21+20+20+22 / 4=20.75 \\
25+21+22+40 / 4=27\end{array}$ & $\begin{array}{c}28+28+22+23 / 4=25.25 \\
28+28+28+28 / 4=28\end{array}$ \\
\hline 15. & $\begin{array}{l}\text { Right } \\
\text { Left }\end{array}$ & $\begin{array}{c}20+20+22+20 / 4=20.5 \\
22+20+20+22 / 4=21\end{array}$ & $\begin{array}{l}25+22+22+30 / 4=24.75 \\
25+22+22+30 / 4=24.75\end{array}$ \\
\hline 16. & $\begin{array}{l}\text { Right } \\
\text { Left }\end{array}$ & $\begin{array}{c}25+23+27+25 / 4=25 \\
29+29+24+28 / 4=27.5\end{array}$ & $\begin{array}{c}22+25+28+30 / 4=26.25 \\
22+25+29+32 / 4=27\end{array}$ \\
\hline 17. & $\begin{array}{l}\text { Right } \\
\text { Left }\end{array}$ & $\begin{array}{c}25+22+25+32 / 4=26 \\
20+22+25+30 / 4=24.25\end{array}$ & $\begin{array}{l}23+24+21+22 / 4=22.5 \\
21+23+22+24 / 4=22.5\end{array}$ \\
\hline 18. & $\begin{array}{l}\text { Right } \\
\text { Left }\end{array}$ & $\begin{array}{l}26+26+26+28 / 4=26.5 \\
26+26+26+28 / 4=26.5\end{array}$ & $\begin{array}{l}30+26+25+25 / 4=26.5 \\
30+26+25+25 / 4=26.5\end{array}$ \\
\hline 19. & $\begin{array}{l}\text { Right } \\
\text { Left }\end{array}$ & $\begin{array}{c}24+21+25+25 / 4=23.75 \\
25+22+25+24 / 4=24.5\end{array}$ & $\begin{array}{c}22+22+22+32 / 4=24.5 \\
23+22+22+30 / 4=24.25\end{array}$ \\
\hline 20. & $\begin{array}{l}\text { Right } \\
\text { Left }\end{array}$ & $\begin{array}{c}25+25+25+29 / 4=26 \\
26+26+25+38 / 4=28.75\end{array}$ & $\begin{array}{c}25+25+25+33 / 4=27 \\
25+25+25+40 / 4=28.75\end{array}$ \\
\hline 21. & $\begin{array}{l}\text { Right } \\
\text { Left }\end{array}$ & $\begin{array}{l}28+28+29+30 / 4=28.75 \\
42+39+43+45 / 4=42.25\end{array}$ & $\begin{array}{l}35+32+30+32 / 4=31.75 \\
35+35+34+35 / 4=34.75\end{array}$ \\
\hline 22. & $\begin{array}{l}\text { Right } \\
\text { Left }\end{array}$ & $\begin{array}{c}26+27+22+40 / 4=28.75 \\
24+22+25+35 / 4=26.5\end{array}$ & $\begin{array}{l}22+21+24+30 / 4=24.75 \\
40+45+53+58 / 4=48.25\end{array}$ \\
\hline 23. & $\begin{array}{l}\text { Right } \\
\text { Left }\end{array}$ & $\begin{array}{c}26+26+25+27 / 4=26 \\
25+26+27+28 / 4=26.5\end{array}$ & $\begin{array}{c}27+27+28+28 / 4=27.5 \\
27+27+28+30 / 4=28\end{array}$ \\
\hline
\end{tabular}

\section{Inference}

The pre-RT and post-RT change in decibels of Left ear and right ear were tested using paired t-test and were found to be statistically not significant $(p=0.21)$ and $(p=0.81)$ respectively.

The change in $\mathrm{dB}$ in the right ear between pre- and post-RT among SIB and SEQ were found to be non- significant ( $p=0.78$ ).

The change in $\mathrm{dB}$ in the left ear between pre- and post-RT among SIB and SEQ were found to be non- significant ( $p=0.44)$.

Thus, there was no significant difference between pre and post-RT hearing loss, indicating that there was not much effect on auditory system in both the different arms of IMRT.

Thus, there was no significant difference between pre and post-RT hearing loss, indicating that there was not much effect on auditory system in both the different arms of IMRT.

\section{DISCUSSION}

Hearing losses in patients post-radiotherapy are predominately mild and of sensorineural type. SNHL is caused by a lesion in the cochlea or retrocochlear component of the auditory system. Though in the index study, only 2 ears developed sensorineural hearing loss.

Though the precise mechanism of radiation-induced hearing loss is not clear, studies on animal cochleae post-radiotherapy have shown ultrastructural changes in the Outer Hair Cells (OHCs) and striavascularis of the basal turn leading to hearing loss [12]. In a study done by Bhandare $\mathrm{N}$ et al., the dose of radiotherapy that reached the auditory system was related to the level of complications; the incidence of ototoxic effects increased as the dose of radiotherapy increased [13]. The underlying cause of hearing loss differs in different patients, depending on the location of radiotherapy induced damage to the inner ear. Radiotherapy can also cause damage to various structures of middle ear, like eustachian tube dysfunction (causing otitis media with effusion), thickening of the tympanic membrane and middle ear fibrosis leading to conductive hearing loss. Mixed hearing losses are mostly seen after RT to malignancy of nasopharynx [3]. In the present study, the number of conductive and mixed hearing loss constituted $50 \%$ of the ears; mainly caused due to eustachian tube dysfunction.

The incidence of hearing loss increases in patients receiving concurrent $\mathrm{CT}+\mathrm{RT}$ [3]. In concurrent chemoradiotherapy, both cisplatin and radiation are known to cause hearing loss independently. Irreversible hearing loss caused by cisplatin administration has been closely investigated, with numerous causative factors identified, like total dose of cisplatin received, mode of drug administration, concurrent use of other ototoxic drugs and renal derangement of the patient [1].

Schultz $\mathrm{C}$ et al., concluded that hearing loss was mostly mild sensorineural in $51 \%$ patients, followed by mixed hearing loss (16.3\%) and conductive hearing loss $(0.7 \%)$ whereas in the present study, most of the patients had mild conductive hearing loss [4]. Secretory otitis media secondary to radiotherapy arises from eustachian tube dysfunction, which accounts for conductive hearing loss in head and neck cancer patients $[8,14,15]$. Tympanometry on head and neck cancer patients, revealed B-type of curve, leading to conductive and mixed hearing loss in their patients. In the present study also, 12 patients had type $\mathrm{C}$ curve and 4 patients had type $\mathrm{B}$ curve, leading to conductive and mixed hearing loss in patients [3]. Anteunis LJ et al., reported that the initial air-bone gap was more at $2 \mathrm{kHz}$ and $4 \mathrm{kHz}$, indicative of changes in the middle ear caused by radiotherapy [16].

Whereas many authors have studied the effect of individual toxicities of radiation and cisplatin on the auditory system, few clinical studies have evaluated the synergistic ototoxic effects of radiation and cisplatin chemotherapy. It has been seen that combined modality treatment involving cochleotoxic compounds such as cisplatin and radiotherapy may have synergistic detrimental effects on inner ear, causing immediate and delayed SNHL [17-24]. Thus, while evaluating the results, it is important to differentiate between radiation and cisplatin-induced ototoxicity separately.

Usually, cisplatin ototoxicity occurs acutely, with effects seen within 3-4 days after administration. Hearing loss initially is more in the high frequencies, which later on may involve the lower frequencies, as the duration of cisplatin administration increases. The hearing loss is usually bilateral, irreversible, and progressive type in such cases [25-27]. 
Radiation-induced ototoxicity, typically becomes evident after 6-12 months post- radiotherapy [28-30]. Aggravating factors include old age and coexisting middle ear pathology [29,31,32]. Grau C et al., and Chen WC et al., advocated that tolerance dose of cochlea in head and neck cancer patients is usually 50 and 60 Gy respectively, with significant increase of hearing loss in patients receiving more than the above thresholds $[31,33]$. Recently, studies by Honoré HB et al., and Pan CC et al., showed increased risk of SNHL with increasing age and presence of previous hearing loss before radiotherapy [34,35]. Conversely, study by Liberman $\mathrm{PH}$ et al., concluded that SNHL was not associated with total radiation dose or with amount of dose received by inner ear [36]. All the above studies were conducted on patients receiving radiation only and no chemotherapy. Hence, these studies are not applicable to those patients receiving both chemotherapy and radiotherapy.

A study by Borsanyi $\mathrm{S}$ et al., showed that $4,000 \mathrm{~Hz}$ frequency had greatest hearing loss and the least affected frequency was $2,000 \mathrm{~Hz}$ [7]. Novotony $\mathrm{O}$ also observed greater loss in range of 4,0008,000 Hz frequency [37]. Kwong DL et al., in their study on patients treated for nasopharyngeal carcinoma, reported SNHL for higher frequency in 43.1 and $54.8 \%$ patients for RT alone and both chemoradiotherapy respectively [29].

It has also been seen that patients with untreated hearing loss were more isolated, with more feelings of loneliness, depression, worry, anxiety, and paranoia $[38,39]$. Such patients are involved in fewer social activities and are not able to integrate information regarding their environment. Hearing loss affects psychosocial environment of these patients and, if untreated, leads to social isolation and low self-esteem. HL also seems to be a cofactor leading to senile dementia [40].

\section{LIMITATION}

The number of patients in our study were less. So, more studies with higher number of patients are required to draw any inference from the results.

A control group was not added, where the effect of only radiotherapy or chemotherapy could be compared with combined chemoradiotherapy.

\section{CONCLUSION}

In the index study, hearing loss in patients treated on Linear Accelerator-Varian Unique Performance with 6MV photon over 6.5 weeks either by sequential IMRT (SEQ) or by IMRT (SIB) had no difference in both the arms. Most of the patients developed mild hearing loss before and after chemoradiotherapy, indicating that both the arms of IMRT (radiotherapy) did not have any major influence on the inner ear. Thus, to conclude, the two arms of IMRT did not have much influence on the auditory nerve, though Eustachian tube dysfunction was evident in both the arms.

\section{REFERENCES}

[1] Goel HC, Laad P, Naik A. The study of auditory effects after concomitant radiotherapy and chemotherapy in patients with head and neck cancer. Indian Journal of Otology. 2013;19(3):136-39.

[2] Dinshaw KA, Shastri SS, Patil SS. Cancer control programme in india: Challenges for the new millennium. Health Admin. 2002;XVII:10-13.

[3] Malgonde MS, Nagpure PS, Kumar M. Audiometric patterns in ototoxicity after radiotherapy and chemotherapy in patients of head and neck cancers. Indian Journal of Palliative Care. 2015;21(2):164-67.

[4] Schultz C, Goffi-Gomez MV, Pecora Liberman PH, Pellizzon A, Carvalho AL. Hearing loss and complaint in patients with head and neck cancer treated with radiotherapy. Arch Otolaryngol Head Neck Surg. 2010;136(11):1065-69.

[5] Lambert EM, Gunn GB, Gidley PW . Effects of radiation on the temporal bone in patients with head and neck cancer. Head Neck. 2016;38:1428-35.

[6] Mujica-Mota MA, Lehnert S, Devic S, Gasbarrino K, Daniel SJ. Mechanisms of radiation-induced sensorineural hearing loss and radioprotection. Hear Res. 2014;312:60-68
[7] Borsanyi S, Blanchard CL, Thorne B. Effect of ionizing radiation on the ear. Ann Otol Rhinol Laryngol 1962; 70: 255-62.

[8] Leach W. Irradiation of the ear. J Laryngol Otol 1965; 79: 870-80.

[9] Zandonai AP, Cardozo FMC, Nieto ING, Sawada NO Qualidade de vida nos pacientes oncológicos: Revisão integrativa da literatura latino-americana. Rev Rev Eletrônica Enferm. 2010;12:554-61.

[10] Pearson SE, Meyer AC, Adams GL, Ondrey FG. Decreased hearing after combined modality therapy for head and neck cancer. Am J Otolaryngol. 2006; 27(2):76-80

[11] Zhang Y1, Lin ZA, Pan JJ, Zheng Z, Yang L, Lin SJ, et al. Concurrent contro study of different radiotherapy for primary nasopharyngeal carcinoma: intensitymodulated radiotherapy versus conventional radiotherapy [in Chinese]. Ai Zheng. 2009;28(11):1143-48

[12] Akmansu H, Eryilmaz A, Korkmaz H, Sennaro glu G, Akmansu M, Göçer C, et al. Ultrastructural and electrophysiologic changes of rat cochlea after irradiation. Laryngoscope. 2004:114:1276-80.

[13] Bhandare N, Antonelli PJ, Morris CG, Malayapa RS, Mendenhall WM. Ototoxicity after radiotherapy for head and neck tumors. Int J Radiat Oncol Biol Phys. 2007;67(2):469-79.

[14] Dias A. Effects on hearing of patients treated with irradiation of head and neck area. J Laryngol Otol 1966;80:276-87.

[15] Young YH, Cheng PW, Ko JY. A 10 year longitudinal study of tubal function in patients with nasopharyngeal carcinoma after irradiation. Arch Otolaryngol Head Neck Surg 1997;123:945-48.

[16] Anteunis LJ, Wanders SL, Hendriks JJ, Langendijk JA, Manni JJ, de Jong JM. A prospective longitudinal study on radiation-induced hearing loss. Am J Surg 1994;168:408-11.

[17] Grau C, Overgaard J. Postirradiation sensorineural hearing loss: A common but ignored late radiation complication. Int J Radiat Oncol Biol Phys 1996;36:515-7.

[18] Plowman PN. Post-radiation sensorineural hearing loss. Int J Radiat Oncol Bio Phys 2002;52:589-91.

[19] Schell MJ, McHaney VA, Green AA, Kun LE, Hayes FA, Horowitz M, et al. cisplatin with or without prior cranial irradiation. J Clin Oncol 1989;7:754-60.

[20] Miettinen S, Laurikainen E, Johansson R, Minn H, Laurell G, Salmi TT. Radiotherapy enhanced ototoxicity of cisplatin in children. Acta Otolaryngol Suppl 1997;529:90-94.

[21] Fukunaga-Johnson N, Sandler HM, Marsh R, Martel MK. The use of 3D conformal radiotherapy to spare the cochlea in patients with medulloblastoma. Int $\mathrm{J}$ Radiat Oncol Biol Phys 1998;41:77-82.

[22] Huang E, Teh BS, Strother DR, Davis QG, Chiu JK, Lu HH, et al. Intensitymodulated radiation therapy for pediatric medulloblastoma: Early report on the reduction of ototoxicity. Int J Radiat Oncol Biol Phys 2002; 52: 599-605.

[23] Sataloff RT, Rosen DC. Effects of cranial irradiation on hearing acuity: A review of the literature. Am J Otol 1994;15:772-80.

[24] Fong RS, Beste DJ, Murray KJ. Pediatric sensorineural hearing loss after temporal bone radiation. Am J Otol 1995;16:793-6l.

[25] Kopelman J, Budnick AS, Sessions RB, Kramer MB, Wong GY. Ototoxicity of high-dose cisplatin by bolus administration in patients with advanced cancers and normal hearing. Laryngoscope 1988;98:858-64.

[26] Fausti SA, Schechter MA, Rappaport BZ, Frey RH, Mass RE. Early detection of cisplatin ototoxicity. Selected case reports. Cancer 1984;53:224-31.

[27] Piel I, Meyer D, Perlia CP, Wolfe VI. Effects of cisdiamminedichloriplatinum (NSC 119875) on hearing function in man. Cancer Chemother Rep 1974;58:871-75.

[28] Ho WK, Wei WI, Kwong DL, Sham JS, Tai PT, Yuen AP, et al. Longterm sensorineural hearing deficit following radiotherapy in patients suffering from nasopharyngeal carcinoma: A prospective study. Head Neck 1999;21:547-53.

[29] Kwong DL, Wei WI, Sham JS, Ho WK, Yuen PW, Chua DT, et al. Sensorineura hearing loss in patients treated for nasopharyngeal carcinoma: A prospective study of the effect of radiation and Cisplatin treatment. Int J Radiat Oncol Bio Phys 1996;36:281-89.

[30] Fuss M, Debus J, Lohr F, Huber P, Rhein B, Engenhart-Cabillic R, et al. Conventionally fractionated stereotactic radiotherapy (FSRT) for acoustic neuromas. Int J Radiat Oncol Biol Phys 2000;48:1381-87.

[31] Grau C, Moller K, Overgaard M, Overgaard J, Elbrønd O. Sensori-neural hearing loss in patients treated with irradiation for nasopharyngeal carcinoma. Int J Radiat Oncol Biol Phys 1991;21:723-28.

[32] Oh YT, Kim CH, Chai JH, Kang SH, Chun M. Sensory neural hearing loss after concurrent cisplatin and radiation therapy for nasopharyngeal carcinoma. Radiother Oncol 2004;72:79-82.

[33] Chen WC, Liao CT, Tsai HC, Yeh JY, Wang CC, Tang SG, et al. Radiation-induced hearing impairment in patients treated for malignant parotid tumour. Ann Otol Rhinol Laryngol 1999;108:1159-64.

[34] Honoré HB, Bentzen SM, Moller K, Grau C. Sensori-neural hearing loss after radiotherapy for nasopharyngeal carcinoma: Individualized risk estimation. Radiother Oncol 2002;65:9-16

[35] Pan CC, Eisbruch A, Lee JS, Snorrason RM, Ten Haken RK, Kileny PR. Prospective study of inner ear radiation dose and hearing loss in head-and-neck cancer patients. Int J Radiat Oncol Biol Phys 2005;61:1393-402.

[36] Liberman PH, Schultz C, Gomez MV, Carvalho AL, Pellizzon AC, Testa JR, et al. Auditory effects after organ preservation protocol for laryngeal/hypopharyngea carcinomas. Arch Otolaryngol Head Neck Surg 2004;130:1265-68.

[37] Novotony O. Effect of X-rays on cochlea of guinea pig. Arch Ital Otol Rinol Laringol 1951;62:15-19.

[38] Pugh KC, Crandell CC. Hearing loss, hearing handicap, and functional health status between African American and Caucasian American seniors. Jam Acad Audiol. 2002;13(9):493-502. 
[39] Kramer SE, Kapteyn TS, Kuik DJ, Deeg DJH. The association of hearing impairment and chronic diseases with psychosocial health status in older age. JAging Health. 2002;14(1):122-137.
[40] Zuur CL, Simis YJ, Lamers EA,et al. Risk factors for hearing loss in patients treated with intensity-modulated radiotherapy for head-and-neck tumors. Int $J$ Radiat Oncol Biol Phys. 2009;74(2):490-96.

PARTICULARS OF CONTRIBUTORS:

1. Assistant Professor, Department of ENT, Institute of Medical Sciences, Banaras Hindu University, Varanasi, Uttar Pradesh, India.

2. Junior Resident, Department of Radiotherapy, Institute of Medical Sciences, Banaras Hindu University, Varanasi, Uttar Pradesh, India.

3. Associate Professor, Department of Radiotherapy and Radiation, Institute of Medical Sciences, Banaras Hindu University, Varanasi, Uttar Pradesh, India.

4. Associate Professor, Department of Radiotherapy and Radiation, Institute of Medical Sciences, Banaras Hindu University, Varanasi, Uttar Pradesh, India

5. Senior Consultant, Apex Hospital, Institute of Medical Sciences, Banaras Hindu University, Varanasi, Uttar Pradesh, India.

\section{NAME, ADDRESS, E-MAIL ID OF THE CORRESPONDING AUTHOR:}

Dr. Sunil Choudhary,

Associate Professor, Department of Radiotherapy and Radiation, Institute of Medical Sciences, Banaras Hindu University,

Varanasi, Uttar Pradesh, India.

E-mail: drsunil104@gmail.com

Date of Submission: Jul 25, 2019

Date of Peer Review: Jul 27, 2019

Date of Acceptance: Aug 06, 2019

FINANCIAL OR OTHER COMPETING INTERESTS: None.

Date of Publishing: Oct 01, 2019 